\title{
220203 エタノール噴霧の既燃ガスジェット着火現象 Ignition Phenomena of Ethanol Spray by Burnt Gas Jet
}

\author{
$\bigcirc$ 野原 健司(芝浦工大院) 正 斎藤 寛泰(芝浦工大)
}

Kenji NOHARA, Shibaura Institute of Technology, 3-7-5 Toyosu, Koto-ku Tokyo, 135-8548, Japan Hiroyasu SAITOH, Shibaura Institute of Technology, 3-7-5 Toyosu, Koto-ku Tokyo, 135-8548, Japan

\begin{abstract}
In this study, we experimentally investigated the effects of burnt gas jet ignition on ethanol spray combustion using a constant volume combustion vessel with a sub chamber. The ignition and combustion phenomena were observed by using a high-speed video camera, and combustion pressure history was measured as well. In case of burnt gas jet ignition, compared with a conventional spark plug ignition, stronger luminous flames were observed, and rate of pressure rise and maximum overpressure much increased. Moreover, it was confirmed that measured HCHO concentration of the burnt gas in the combustion vessel remained at low level although the amount of ethanol related to combustion reaction increased. It is mainly due to the strong turbulent mixing effects of the hot burnt gas jet and the spray flows.
\end{abstract}

Key Words: Burnt Gas Jet Ignition, Ethanol, Spray, Hydrogen, HCHO

\section{1. 諸喆}

近年, 燃焼器から排出される有害物質による環境污染や 化石燃料枯渴の問題により, 燃焼器のさらなるクリーン化 や燃費の向上，非石油由来の代替燃料への移行が急務とさ れている. 有害物質の排出低減や燃費向上の有効な手段之 して，希薄燃焼方式がある。しかし，内燃機関等の燃焼器 の多くが採用するスパークプラグは“点”での着火である ため, 混合気の着火はスパークプラグ周囲の混合気濃度や 流速等の条件に大きく依存し, 確実な希薄燃焼を行うため には, 燃焼器内の流れを制御して成層燃焼を行わせるなど の工夫を必要とする．近年, このスパークプラグに変わる 新たな着火方法がいくつか提唱されており，そのうちの一 つに，高温の既燃ガスジェットの吹き込みによる着火方法 がある。これは，主燃焼室に隣接して設けた“副燃焼室” に, 安定して着火・燃焼できる少量の混合気を充填し，そ の混合気の燃焼によって生成した高温の燃焼ガスジェット の吹き込みにより，主燃焼室の燃料を“体積的”に着火さ せ，混合気の安定した着火と燃焼促進を図る方法である。 これまで,このような体積的着火に着目した研究が森・吉 川ら (1)(2)や村瀬ら ${ }^{(3)(4)} に よ り$ 行われ, その効果が調べられて いるが，燃料に噴霧状の液体燃料を使用した例はほとんど 報告されていない，そこで，本研究では，既燃ガスジェッ 卜を生成する装置を用い，定容燃焼器内における液体燃料 噴霧の既燃ガスジェット着火現象，および，その燃焼特性 について調べた. 本研究では, 主燃焼室に充填する燃料に,

代替燃料として期待されているエタノールを使用し，副燃 焼室内には可燃範囲が広く, 燃焼速度の速い水素-空気混合 気を充填した。エタノールは，特に低温環境における始動 が悪く，また，人体に有害なアルデヒド類を排出する(5)な ど課題も多い燃料である，そこで，簡易的な計測ではある が, 燃焼ガス中のHCHO濃度を検出器によって計測し, 排 Table 1 Experimental condition

\begin{tabular}{|c|c|c|c|c|c|c|}
\hline \multicolumn{3}{|c|}{ Experimental condition } & (a) & (b) & (c) & (d) \\
\hline \multicolumn{3}{|c|}{ Inifial filling gass } & Dyy air & $\begin{array}{c}\mathrm{Dny} \\
+2 \mathrm{vol} \% \mathrm{H}_{2}\end{array}$ & Dry air & Dry air \\
\hline \multirow{3}{*}{$\begin{array}{l}\text { Main combus tion } \\
\text { chanther }\end{array}$} & \multicolumn{2}{|c|}{$\begin{array}{l}\text { Injection pressure } \\
\text { (Ethanol) }\end{array}$} & \multicolumn{4}{|c|}{7 |MPa| } \\
\hline & \multicolumn{2}{|c|}{$\begin{array}{l}\text { Amount of fuel } \\
\text { consunption }\end{array}$} & \multicolumn{4}{|c|}{$52.7|\mathrm{mg}|$} \\
\hline & \multicolumn{2}{|c|}{$\begin{array}{c}\text { Equivalence ratio } \\
\text { (Ethanot-air) }\end{array}$} & \multicolumn{4}{|c|}{0.4} \\
\hline \multirow{6}{*}{$\begin{array}{l}\text { Pre sombustion } \\
\text { chamber }\end{array}$} & \multirow{2}{*}{$\begin{array}{l}\text { Injection } \\
\text { pressure }\end{array}$} & Hydrogen & & & \multicolumn{2}{|c|}{$0.2|\mathrm{MPa}|$} \\
\hline & & Dny air & & & \multicolumn{2}{|c|}{$0.2|\mathrm{MPa}|$} \\
\hline & \multirow{2}{*}{$\begin{array}{l}\text { Amount of fucl } \\
\text { consunpption }\end{array}$} & Hydrogen & & & \multicolumn{2}{|c|}{$1+\left|\mathrm{cm}^{3}\right|$} \\
\hline & & Dn nir & & & \multicolumn{2}{|c|}{$16\left|\mathrm{~cm}^{3}\right|$} \\
\hline & \multicolumn{2}{|c|}{$\begin{array}{l}\text { Equivalence matio } \\
\text { (Hydrogen-air) }\end{array}$} & ... & & \multicolumn{2}{|c|}{2.1} \\
\hline & \multicolumn{2}{|c|}{ Orifice } & & & no & $12|\mathrm{~mm}|$ \\
\hline
\end{tabular}

出特性を調べた.

\section{2. 実験装置および方法}

図1に, 本実験で用いた実験装惪の概略を示す. 主燃焼室 は $\phi 110 \mathrm{~mm} \times 106 \mathrm{~mm}$ の容積約 $1000 \mathrm{~cm}^{3}$ の円筒形状, 副燃 焼室は $\phi 24 \mathrm{~mm} \times 40 \mathrm{~mm}$ の容積約 $30 \mathrm{~cm}^{3}$ の円筒形状である. 主燃焼室下部の副燃焼室は, 比較実験を行うため, スパー クプラグ取り付け用のフランジと取り換えられるようにな っている. 主燃焼室の両側面には強化ガラスの観察空, 上 部に液体燃料微粒化用のインジェクタ（DENSO，トヨタ 3S-FSEエンジン用インジェクタ)，下部に副燃焼室を配㯰 し, 側面に圧カセンサ (共和電業, PHL-A-5MP)，および, 吸気・排気のためのポートを設けている．副燃焼室上部に は，噴出口直径を変更するために脱着可能としたオリフィス (直径 $d: 3.6 \mathrm{~mm}, 5.4 \mathrm{~mm}, 7.2 \mathrm{~mm}, 9.6 \mathrm{~mm}, 12 \mathrm{~mm}$ ) , 下 部には，スパークプラグと副燃焼室内の圧力モニタ用圧力 センサ（共和電業, PHL-A-3MP)，および, ガス充填用の ポートを2つ設けている. 本実験では, 気体然料用インジェ クタ（ケーヒン，06164-PDN-J00）を用いて副燃焼室側面 からガスを充填させた。また，副燃焼室充填ガスには，乾 燥空気および水素を使用した。また，オリフィスは，直径 $d=12 \mathrm{~mm}$ のものを用い, オリフィスなしの場合と比較実験 を行った.さらに,スパークプラグ着火との比較も行った.

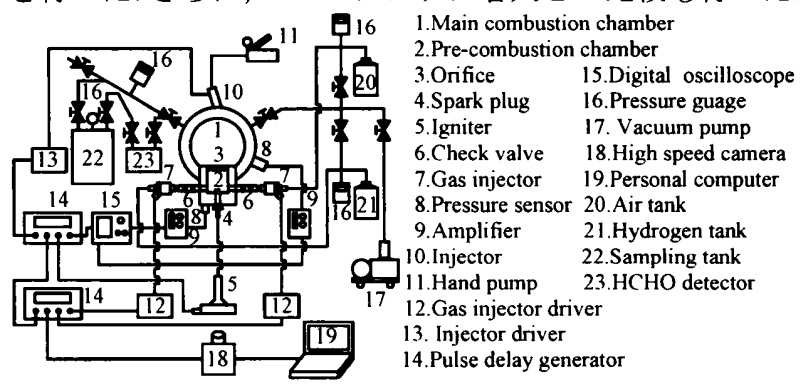

Fig. 1 Experimental setup

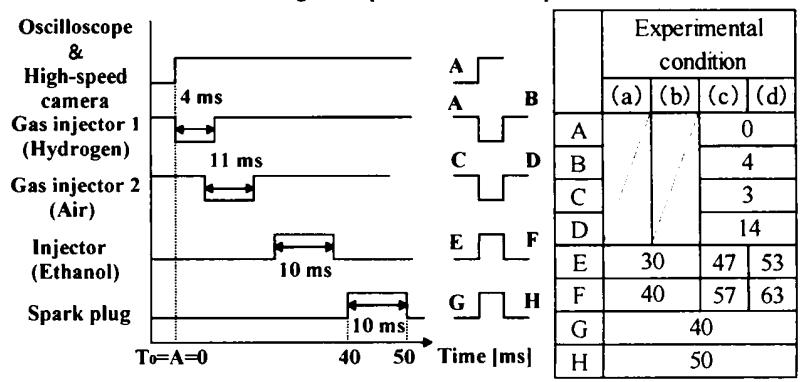

Fig.2 TTL signal

日本機械学会関東支部第 17 期総会講演会講演論文集 [’11-3.18,19,横浜] 
次に，実験手順を概説する，まず，主・副燃焼室内部お よび配管内を空気により十分に掃気する。そい後, 真空ポ ンプにより真空引きを行い, 乾燥空気を所定の初気圧力 $P_{0}$ になるようにボンベから充填する。本実験では， $P_{0}$ を0.1 $\mathrm{MPa}$, 初期温度 $T_{0}$ を室温 $\left(23^{\circ} \mathrm{C}\right.$ 程度）とした。 その後, 手 動ポンプ（RIKEN，WP-1B-255）により，エタノールに圧 力をかけておき，レギュレータにより水素および空気の噴 射圧を設定する。設定後，パルスディレイジェネレータ

(STANFORD RESERCH SYSTEMS, DC535) から出力さ れるTTL信号により，エタノール，水素，空気の各噴射量

(噴射期間) およびスパークタイミングを制御し，各噴射 および着火を行う。上昇する燃焼室内圧力を主・副燃焼室 に取り付けた圧力センサで検知し，燃焼の様了・を高速度力 メラ（フォトロン，FASTCAM-NEO）により観測する。圧 カセンサからの圧力信岇は, アンプ (ユニパルス, AM32 共 和電業, DPM-602A）により増幅され, デジタルオシロス コープ（横河電機，DL750P）に取り込まれ，記録される. 画像撮影のフレームレートは, 条件に応じて, $1500 \mathrm{fps} よ$ び2000 fpsとした.オシロスコープのサンプリング周波数は $25 \mathrm{kHz}$ である。撮影画像は，PCに送られ保存される，燃焼 完了後, 容器内の燃焼ガスをサンプリング容器に移し, 燃 焼ガスを計測可能範囲まで希䣋した後，ホルムアルデヒド 検知器（理研計器, FP-30) により HCHO濃度を計測する. なお，本研究では，最大過圧力（ゲージ圧）を $\Delta P_{\max }$, 副燃 焼室に取り付けられたプラグが放電を開始する時間 $\left(t_{\text {spark }}=50 \mathrm{~ms}\right)$ を基準に燃焼室の圧力が最大值をとるまで の時間を $\Delta t$ と定義する. 各機器の同期をとるために用いた TTL信号のタイミングを図2に，実験条件を表1に示す，着 火実験は，各条件10回ずっ行った。

\section{3. 実験結果および考察}

各実験条件における，時系列画像を図 3（a）〜（d）に 示す. 画像は火炎発光が確認された時刻付近のもので, $8 \mathrm{~ms}$ おきに示している。（a）エタノールのみ，および，(b) 副燃焼室内に充填したのと同量程度の水素を予め添加し， スパークプラグで着火・燃焼を行った場合に比べ，既然ガ スジェットの吹き込みで着火させた（c），（d）の条件で は, 強い火炎発光が広範囲に発生していることが確認でき る。これは，高温の既燃ガスジェットとエタノール噴霧流 が乱流混合し, エタノール噴霧の分散, 蒸発, 混合が促進 された結果であると考えられる。このときの燃焼圧力履歴 の例を比較したものを図 4 に示す。投入エタノール量は同 じであるが，既燃ガスジェット着火はスパークプラグ着火 に比べて圧力上昇が大きく，最大過圧力も増大することが 見てとれる。この圧力履眐から， $\Delta P_{\max }$ および $\Delta t$ を求めた ものを図 5（i ），（ii）に示す．既然ガスジェット着火 により発生する $\Delta P_{\max }$ はスパークプラグ着火の数倍となり, $\Delta t$ がおよそ半分以下となっていることがわかる。既燃ガス ジェット着火の燃焼促進効果は, オリフィス径にも依存す ると考えられ，口径の最適化を行えば，着火・燃焼促進効 果のさらなる向上を図ることができると考えられる. 図 6 は, 燃焼ガス中 HCHO 濃度の比較である. 図 6 より, 各条 件での HCHO 濃度は（a）<（d）<（b）<（c）の順に少 なくなる結果が得られた.スパークプラグ着火の (a)，(b) の条件はエタノールの燃焼量が少ないため， (c)， (d) の条件とは比較できないが，より多くのエタノールを燃焼 させたと考えられる条件 (d) の HCHO 濃度レベルが低く なった。過圧力, 燃焼時間, および, $\mathrm{HCHO}$ 濃度を考慮す れば,これらの条件の中では条件（d）が最も良好な燃焼状 態であり，既燃ガスジェットによる燃焼促進の効果が大き かったと推測できる.

4.まとめ

既燃ガスジェットがエタノール噴霧の着火および燃焼に
及ぼす影響を, 定容燃焼容器を用いた着火実験により検討 した。その結果, 噴霧燃料においても, 高温の既燃ガスジ エットの吹き込みによって強い燃焼促進効果が得られるこ とがわかった。また，燃焼量が増加するにも関わらす HCHO 排出量を減少させることが可能であることもわかった。こ れは既燃ガスジェットとの乱流混合により, 噴霧の分散, 蒸発, 混合が進み, 燃焼が良好になったためであると考え られる。

謝辞

本研究の遂行にあたり，文部科学省科学研究費（研究代表者： 斎藤寛泰, 若手研究 (B)，H17-18, 課題番号 17760163 および研 究代表者: 斎藤寛泰 (B) , H20-21, 課題番号 20760131）の支援 を受けたっここに謝意を表す。

\section{参考文献}

（1）森，燃焼の科学と技術，5，103-111 (1997)，(2) 吉川，日本燃焼学 会誌, 49-148,112-117，(2007)，(3) 村瀬, 機論 (B 編)，59-568， 294-300(1993)，(4) 村瀬, 機論 (B 編)，64-617, 312-319(1998)，(5) 矢野, 機論 (B 編) , 32-473, 238-247(1986).

(a)
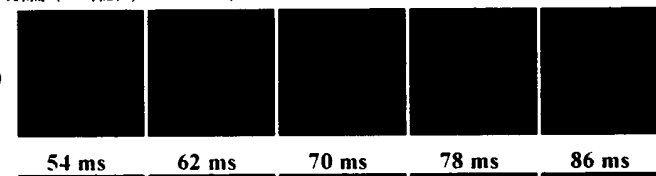

(b)

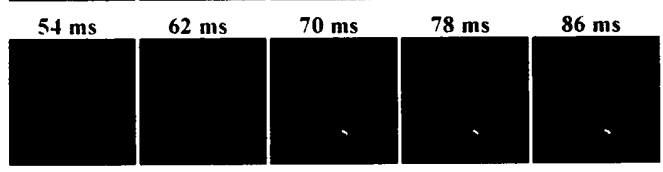

(c)

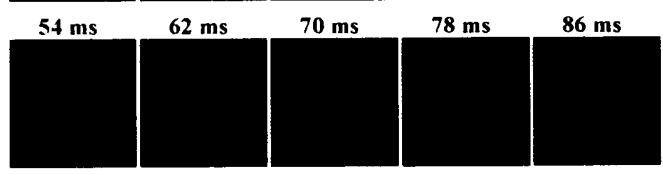

(d)

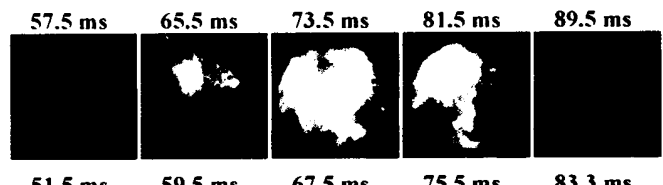

$51.5 \mathrm{~ms}$

$59.5 \mathrm{~ms}$

$67.5 \mathrm{~ms}$

$83.3 \mathrm{~ms}$

Fig. 3 Time-series images of the flame

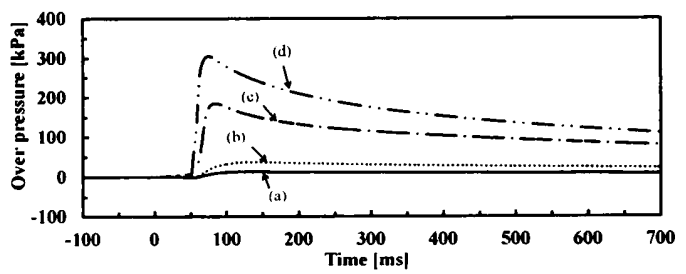

Fig.4 Comparison of pressure history
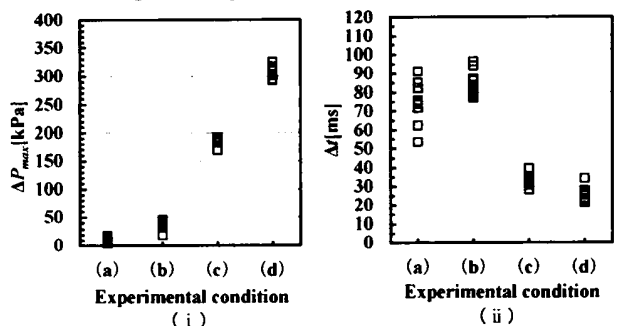

Fig. 5 Comparison of

(i ) $\Delta P$,

(ii ) $\Delta t$

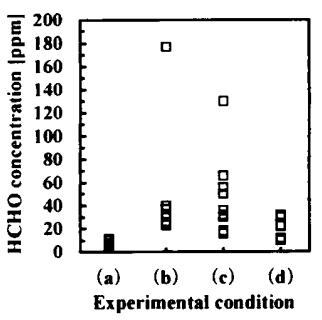

Fig. $6 \mathrm{HCHO}$ concentration 